\title{
GIS Mapping and Background Ionizing Radiation (BIR) Assessment of Solid Mineral Mining Sites in Enugu State, Nigeria
}

\author{
Jude Chukudi Osimobi' ${ }^{1}$, Ezekiel Oghenenyerhovwo Agbalagba², \\ Gregory Onomakere Avwiri'1, Chinyere Patience Ononugbo ${ }^{1}$ \\ ${ }^{1}$ Department of Physics, University of Port Harcourt, Port Harcourt, Nigeria \\ ${ }^{2}$ Department of Physics, Federal University of Petroleum Resources, Effurun, Nigeria \\ Email: ezek64@yahoo.com, osimobijude@gmail.com, goavwiri@yahoo.com
}

Received 13 October 2015; accepted 27 October 2015; published 30 October 2015

Copyright (C) 2015 by authors and OALib.

This work is licensed under the Creative Commons Attribution International License (CC BY). http://creativecommons.org/licenses/by/4.0/

(c) (i) Open Access

\section{Abstract}

A study of the external background ionizing radiation (BIR) levels in eight solid mineral mining sites in Enugu State has been carried out using two Digilert radiation monitors Radalart-50 and Radalart-100. Thirty two readings of four sampling in each point were taken at different solid mineral sites of the state following standard procedure. The measured BIR levels obtained ranged from $0.012 \mathrm{mR} / \mathrm{hr}$ in Nkpologwu silica mining site to $0.028 \mathrm{mR} / \mathrm{hr}$ in clay mining site in EnuguEkulu with an average of $0.018 \pm 0.004 \mathrm{mR} / \mathrm{hr}$, while the corresponding calculated equivalent dose rate ranged from $1.0 \mathrm{mSv} / \mathrm{yr}$ to $2.35 \mathrm{mSv} / \mathrm{yr}$ with a mean value of $1.51 \pm 0.04 \mathrm{mSv} / \mathrm{yr}$. The result obtained indicates that the average exposure level of the studied area is $38.5 \%$ higher than the international standard. This suggests the possibility of the presence of radionuclide in the solid minerals mined in Enugu state. However, the values obtained may not cause immediate health challenge to miners and those engaging in commercial activities around these mining sites in Enugu, but may result in long-term health side-effects to residence and miners who put in over twenty-five years in the job. From the forgoing, it is recommended that control mechanism should be adopted for the members of the public, residence, commercial traders as well as miners working in these sites, and to protect the environment.

\section{Keywords}

BIR Assessment, GIS Mapping, Solid Mineral, Enugu State

Subject Areas: Environmental Sciences, Nuclear Physics

\section{Introduction}

Man is continually exposed to radiation from natural sources with or without his consent; this phenomenon is

How to cite this paper: Osimobi, J.C., Agbalagba, E.O., Avwiri, G.O. and Ononugbo, C.P. (2015) GIS Mapping and Background lonizing Radiation (BIR) Assessment of Solid Mineral Mining Sites in Enugu State, Nigeria. Open Access Library Journal, 2: e1979. http://dx.doi.org/10.4236/oalib.1101979 
unending and unpredictable. The two main contributors to natural radiation exposures are: high-speed cosmic ray particles incidents in the earth's atmosphere and the primordial radionuclides present in the Earth's crust which are present everywhere, including the human body [1]. Background or terrestrial radiation is the radiation of man's natural environment, consisting of what comes from Cosmic rays, the naturally radioactive elements of the earth and from within human body [2].

The International Atomic Energy Agency (IAEA) estimate of the dose contribution to the environment shows that, over $85 \%$ of background radiation received by man is derived from natural radionuclides, while the remaining $15 \%$ is from cosmic rays and nuclear process [3].

Radiation exposure outdoors arising from terrestrial radionuclides is present in trace levels in all soil types. Radiation emitted by these radionuclides within $15-30 \mathrm{~cm}$ of the topsoil reaches the earth surface [4], with only those radionuclides with half-lives comparable to the age of the earth, and their decay products exist in significant quantities in these materials.

Terrestrial radiations, which comprise ionizing radiation from rocks, solid minerals and soil, vary significantly depending on geographical locations and geological formation [5] [6]. Solid mineral is a crystalline solid of inorganic origin formed as a result of geological processes and has a well-defined chemical composition [7]. They constitute rocks that are found in the earth and exist together with the naturally occurring radioisotopes in the earth crusts. Mining of solid minerals could enhance the exposure of the environment to terrestrial radioisotopes.

Some exposure to natural radiation sources is modified by human activities. Examples are: natural radionuclides released into the environment in mineral processing and the using phosphate fertilizer processing, fossil fuel combustion and quarry activity, causing enhanced natural radiation exposures. Some people are exposed to enhanced levels of natural radiation at their places of work; such workers include underground miners and some workers are involved in mineral processing [8]. While some persons are exposed to the radiation from these solid minerals constantly because of their proximity to mining sites, quarry sites, processing factories or its material utilization companies.

Radiation has no boundaries; and the injuries and clinical symptoms induced by exposure to ionizing radiation include: direct chromosomal transformation, indirect free-radical formation, radiation cataractogenesis, cancer induced, bone necrosis, etc. The practice of protection has ensured that human exposure to radiation is guided by the ALARA principle (ALARA-As Low As Reasonably Achievable). The estimation of exposure to ionizing radiation is therefore an important goal of regulatory authorities and radiation protection scientists. In public health management of radiation emergencies, one of the essential components of integrated assessment is to quickly and accurately assess and categorize the exposure. Thus knowledge of the background radiation level is of paramount importance [9].

Enugu state is endowed with solid mineral resources such as salt, clay, kaolinite, gypsum, limestone, galena, bitumen, dolomite, granite, dolerite, ironstone, silica, glass-sand, etc., some of which are not yet being mined but are being investigated by Enugu State Ministry of Environment and Solid Mineral Development [10]. With the dwindling of income from crude oil and the need to improve the revenue base of the state has resulted in massive mining activities without regards to the associated environmental degradations. Excessive exposure of mine workers and inhabitants of nearby communities to ionizing radiation could result in health side effects. Background ionizing radiation (BIR) levels in these areas are not yet established; hence the need to have a proper documentation of the radiation level so as to provide a base-line data for future research and also estimate the radiological burden on the miners, populace and environment.

\section{Materials and Methods}

This study was conducted in October, 2014 around eight selected mine sites which are located at Enugu, Southeast of Nigeria. The study areas lie within longitudes E007 ${ }^{\circ} 12^{\prime} 58^{\prime \prime}$ and E007 $36^{\prime} 22^{\prime \prime}$, and latitudes N06 $01^{\prime} 46^{\prime \prime}$ and N06 $45^{\prime} 44.4^{\prime \prime}$. Figure 1 shows the map of Enugu state indicating the areas where the mining sites under investigation are located in the state.

An in-situ measurement was achieved using two Digilert radiation monitors, Radalart-50 and Radalart-100. The meter's sensitivity referenced to Cs-137 and its maximum alpha and beta efficiencies are $18 \%$ and $33 \%$ respectively. It has a halogen-quenched Geiger-Muller detector tube of effective diameter of $45 \mathrm{~mm}$ and a mica window density of $1.5-2.0 \mathrm{mg} \cdot \mathrm{cm}^{-2}$ (inspector alert operation manual). 


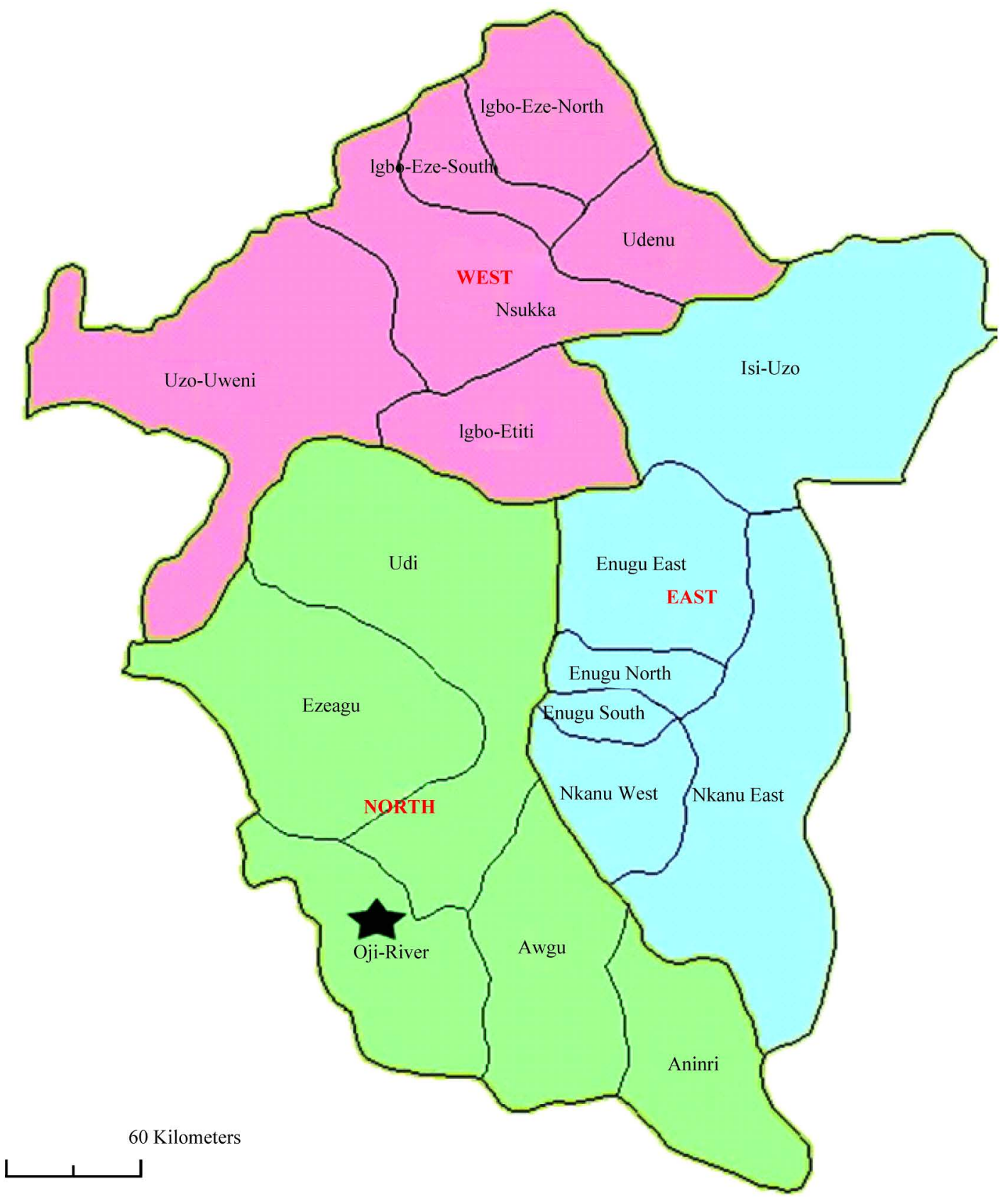

Figure 1. Map of Nigeria showing the study area, Enugu state.

The readings were taken 10 meters apart from a point chosen at random covering a distance of 100 meters of the cardinal points (East, West, North and South) from the solid mineral sites and some neighbouring environment. Also used for the study was a Geographical positioning system (GPS) to locate and map-out the mineral sites. The tube of the radiation monitoring meter was raised to a standard height of $1.0 \mathrm{~m}$ above the ground [11] [12], with its window first facing the suspected source and then vertically downward while the GPS reading taken at that spot. Measurements were repeated three times at each site using the two radiation monitoring meters on different days within the two months to take care of any fluctuation in the environmental radiation. Readings were obtained between the hours of 1300 and 1600 hours, since the radiation meters have the maximum response to environmental radiation within these hours as recommend by NCRP [13]. The radiation meters read directly the BIR levels of the environment. 
To estimate the whole body equivalent dose rate over a period of one year, we use the National Council on Radiation Protection and Measurement recommendations [12] [13].

$$
1 \mathrm{mR} \cdot \mathrm{h}^{-1}=\frac{0.96 \times 24 \times 365}{100} \mathrm{mSv} \cdot \mathrm{y}^{-1}
$$

\section{Result and Discussion}

The results of the background ionizing radiation (BIR) obtained in this study are presented in Table 1 . The values presented are the mean of the measurements taken from four coordinates of the various solid mineral sites in the area. From Table 1, the exposure rate (BIR levels and corresponding equivalent dose rate) ranged from $0.015 \mathrm{mR} / \mathrm{hr}(1.26 \mathrm{mSv} / \mathrm{yr})$ to $0.017 \mathrm{mR} / \mathrm{hr}(1.43 \mathrm{mSv} / \mathrm{yr})$ with a mean value of $0.016 \pm 0.005 \mathrm{mR} / \mathrm{hr}(1.37 \pm$ $0.04 \mathrm{mSv} / \mathrm{yr}$ ) in Ogugu limestone mining site. In Enugu-Ekulu clay mining site, the exposure rate ranged from $0.016 \mathrm{mR} / \mathrm{hr}(1.35 \mathrm{mSv} / \mathrm{yr})$ to $0.028 \mathrm{mR} / \mathrm{hr}(2.35 \mathrm{mSv} / \mathrm{yr})$ with a mean value of $0.020 \pm 0.003 \mathrm{mR} / \mathrm{hr}(1.64 \pm$ $0.02 \mathrm{mSv} / \mathrm{yr})$, while in Awgu bitumen mining site, the exposure levels ranged from $0.017 \mathrm{mR} / \mathrm{hr}(1.43 \mathrm{mSv} / \mathrm{yr})$ to $0.020 \mathrm{mR} / \mathrm{hr}(1.68 \mathrm{mSv} / \mathrm{yr})$ with a mean value of $0.019 \pm 0.007 \mathrm{mR} / \mathrm{hr}(1.56 \pm 0.05 \mathrm{mSv} / \mathrm{yr})$. The exposure rate in Awkuke ironstone mining site ranged from $0.015 \mathrm{mR} / \mathrm{hr}(1.26 \mathrm{mSv} / \mathrm{yr})$ to $0.017 \mathrm{mR} / \mathrm{hr}(1.43 \mathrm{mSv} / \mathrm{yr})$ with a mean value of $0.016 \pm 0.005 \mathrm{mR} / \mathrm{hr}(1.37 \pm 0.04 \mathrm{mSv} / \mathrm{yr})$. In Ama-echi silica mining site, the exposure rate (BIR levels and corresponding equivalent dose rate) ranged from $0.013 \mathrm{mR} / \mathrm{hr}(1.09 \mathrm{mSv} / \mathrm{yr})$ to 0.022 $\mathrm{mR} / \mathrm{hr}(1.85 \mathrm{mSv} / \mathrm{yr})$ with a mean value of $0.019 \pm 0.006 \mathrm{mR} / \mathrm{hr}(1.64 \pm 0.09 \mathrm{mSv} / \mathrm{yr})$. The exposure rate ranged from $0.012 \mathrm{mR} / \mathrm{hr}(1.00 \mathrm{mSv} / \mathrm{yr})$ to $0.016 \mathrm{mR} / \mathrm{hr}(1.18 \mathrm{mSv} / \mathrm{yr})$ with a mean value of $0.014 \pm 0.008 \mathrm{mR} / \mathrm{hr}(1.16$ $\pm 0.05 \mathrm{mSv} / \mathrm{yr}$ ) in Uzo Uwani kaoline site, while in Enugu North gypsum site, the exposure rat ranged from $0.012 \mathrm{mR} / \mathrm{hr}(1.00 \mathrm{mSv} / \mathrm{yr})$ to $0.018 \mathrm{mR} / \mathrm{hr}(1.51 \mathrm{mSv} / \mathrm{yr})$ with a mean value of $0.017 \pm 0.002 \mathrm{mR} / \mathrm{hr}(1.37 \pm$ $0.02 \mathrm{mSv} / \mathrm{yr})$. And in Nsude Glass-site, the exposure rate ranges from $0.013 \mathrm{mR} / \mathrm{hr}(1.09 \mathrm{mSv} / \mathrm{yr})$ to 0.016 $\mathrm{mR} / \mathrm{hr}(1.35 \mathrm{mSv} / \mathrm{yr})$ with a mean value of $0.015 \pm 0.001 \mathrm{mR} / \mathrm{hr}(1.2 \pm 0.09 \mathrm{mSv} / \mathrm{yr})$.

The overall measured BIR values obtained ranged from $0.012 \mathrm{mR} / \mathrm{hr}(1.00 \mathrm{mSv} / \mathrm{yr})$ in Nkpologwu Silica mining site to $0.028 \mathrm{mR} / \mathrm{hr}$ in clay mining site in Enugu-Ekulu with an average value of $0.018 \pm 0.004 \mathrm{mR} / \mathrm{hr}$, while the corresponding equivalent dose rate ranged from $1.00 \mathrm{mSv} / \mathrm{yr}$ to $2.35 \mathrm{mSv} / \mathrm{yr}$ with a mean value of 1.51 \pm 0.04 . The average values obtained in the studied areas indicates that the BIR levels were exceeded in ambient and normal background radiation level of $0.013 \mathrm{mRh}^{-1}$. The estimated specific absorption dose rate obtained in all the sites measured is well above $1.0 \mathrm{mSv} / \mathrm{yr}$ permissible limit for the public but is still within the $5 \mathrm{mSv} / \mathrm{yr}$ recommended for occupational exposure for those working in radioactive environment not more than eight hours per day. It was observed from the result that out of the 32 sampled points only 2 points which represent $6.25 \%$ is below the ambient background radiation levels of $0.013 \mathrm{mR} / \mathrm{hr}$ while 30 points representing $93.75 \%$ are above the BIR level. The GIS map in Figure 2 clearly shows all the mineral mining sites/locations where the ambient BIR level of $0.013 \mathrm{mR} / \mathrm{hr}$ is complied with and the areas where it was exceeded, which give the picture of the BIR level of all the mining sites at a glance which also help to appreciate the radiation distribution pattern. Table 2 present the summary of the mean BIR levels and the corresponding equivalent dose rate from each of the sample sites/area. These values obtain from the study were compared with the international standard as shown in Figure 3 \& Figure 4. The values obtained in Figure 3 show a clear departure of the values measured in these mining sites from ambient background ionizing radiation levels and the values are higher than those obtained in similar solid mineral mining sites in Abia State South-East of Nigeria and the background radiation level of Offa industrial area of Kwara State [6] [14]. This is a clear indication that the mining environment of these solid minerals is not totally safe as residential area, but ironically, most of these areas has become a commercial environment where different business are carried out and many reside in this area. This BIR value reported may have some long term side effects on both miners who spends more than eight hour on sites and those residing in these environment. Figure 4 compared the estimated equivalent dose rate values from the measured BIR values with International standard, the Figure 4 shows very clearly that the value estimated from these sites were well above world recommended value of $1.0 \mathrm{mSvy}^{-1}$. The EDR values Obtained ranges from $1.37 \pm 0.04$ $\mathrm{mSy}^{-1}$ to $1.64 \pm 0.24 \mathrm{mSy}^{-1}$. This implies that the radiation dose to man is higher than the world permissive limit. However, these values reported are within the value obtained by Avwiri et al. and Agbalagba and Meindinyo [15] [16] in the oil and gas drilling environment.

To determine how each of the various solid minerals contribute to the total background ionizing area of Enugu state, percentage contribution of each of the solid minerals was estimated and the result is as shown in 
Table 1. Measured values of the BIR from the different solid mineral sites in Enugu state.

\begin{tabular}{|c|c|c|c|}
\hline \multicolumn{4}{|c|}{ BIR at Limestone Site (OGUGU) and Its Environs } \\
\hline Sample Area & Location GPS Readings & BIR (mR/hr) & EDR (mSv/yr) \\
\hline Agbani-Awgu Rd & N0613'16.9" E007²9'13.6" & 0.015 & 1.26 \\
\hline Ogugu Site & N060'56.7" E007²9'07.3" & 0.017 & 1.43 \\
\hline Ogugu Mrkt & N06 09'59" E007 29'11" & 0.016 & 1.35 \\
\hline Ogbaku & N0612'39" E007 30'10" & 0.017 & 1.43 \\
\hline Mean Value & & $0.016 \pm 0.005$ & $1.37 \pm 0.04$ \\
\hline \multicolumn{4}{|c|}{ BIR at Clay Site (Enugu-Ekulu) and Its Environs } \\
\hline Prada Company & N06ํํ'ㄷ.1" E007²7'17.6" & 0.017 & 1.43 \\
\hline Clay Site & N06 09'56.7" E007²9'07.3" & 0.028 & 2.35 \\
\hline Iva Valley & N06 27'54.5" E007'27'21.7" & 0.016 & 1.35 \\
\hline Awkunanaw & N062'18" E007 36'22" & 0.017 & 1.43 \\
\hline Mean Level & & $0.020 \pm 0.003$ & $1.64 \pm 0.02$ \\
\hline \multicolumn{4}{|c|}{ BIR at Bitumen Site (Awgu) and Its Environs } \\
\hline Uguweme & N06 01'46" E007 27'21" & 0.019 & 1.60 \\
\hline Mining Site & N060'27.5" E0072'ㄴ'34.5" & 0.020 & 1.68 \\
\hline Mgbidi & N060'14.6" E007 28'30.5" & 0.018 & 1.51 \\
\hline Ezeama-Awgu & N060'18.7" E007²6'38.3" & 0.017 & 1.43 \\
\hline Mean Value & & $0.019 \pm 0.007$ & $1.56 \pm 0.05$ \\
\hline \multicolumn{4}{|c|}{ BIR at Ironstone Site (Awkuke) and Its Environs } \\
\hline Gariki & N06 19'46" E007 27'21" & 0.019 & 1.60 \\
\hline Mining Site & N06'ㄹ'45.5" E007'27'52.4" & 0.022 & 1.85 \\
\hline Edozie & N06²5'32.1" E007'29'23.2" & 0.020 & 1.68 \\
\hline Awkuke Park & N06룽'18.7" E007²6'38.3" & 0.017 & 1.43 \\
\hline Mean Value & & $0.020 \pm 0.006$ & $1.64 \pm 0.09$ \\
\hline \multicolumn{4}{|c|}{ BIR at Silica Site (Ama-echi) and Its Environs } \\
\hline Ugwu-aji & 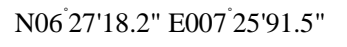 & 0.013 & 1.09 \\
\hline Mining Site & 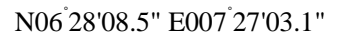 & 0.022 & 1.85 \\
\hline Okiti & N0626'35.8" E007 28'30.5" & 0.023 & 1.93 \\
\hline Agayiba Street & N062'56.2" E007 30'32.3" & 0.017 & 1.43 \\
\hline Mean Value & & $0.019 \pm 0.002$ & $1.58 \pm 0.19$ \\
\hline \multicolumn{4}{|c|}{ BIR at Kaoline Site (Uzo Uwani) and Its Environs } \\
\hline Uvuru & N06 45'00.0" E007 12'58" & 0.015 & 1.26 \\
\hline Mining Site & N06 45'44.4" E007'16'17.0" & 0.016 & 1.18 \\
\hline Nkpologwu & N06 41'17.1" E007²9'23.2" & 0.012 & 1.00 \\
\hline Uvuru Mrkt. & N06ㄴㄱ'16.5" E007²6'38.3" & 0.014 & 1.18 \\
\hline Mean Value & & $0.014 \pm 0.008$ & $1.16 \pm 0.05$ \\
\hline \multicolumn{4}{|c|}{ BIR at Gypsum Site (Enugu/N) and Its Environs } \\
\hline Holy/G Park & N063'ㄱ'" E007 30'32" & 0.018 & 1.51 \\
\hline Mining Site & N06 31'05.5" E007²6'34.5" & 0.021 & 1.77 \\
\hline Ekulu & N062'13.6" E007'28'30.5" & 0.012 & 1.00 \\
\hline Sub-Way & N06 30'12.7" E007'26'38.3" & 0.015 & 1.18 \\
\hline Mean Value & & $0.017 \pm 0.002$ & $1.37 \pm 0.02$ \\
\hline \multicolumn{4}{|c|}{ BIR at Glass-Sand Site (Nsude) and Its Environs } \\
\hline Nsude Junction & N062'ㄹ' E007'29'56" & 0.013 & 1.09 \\
\hline Mining Site & N06ํㄴ'34.5" E007²8'52.4" & 0.018 & 1.51 \\
\hline Market & N06ํㄹ'59.1" E007²3'48.2" & 0.014 & 1.18 \\
\hline Nsude Park & N06²3'22.0" E007'26'18.4" & 0.016 & 1.35 \\
\hline Mean Value & & $0.015 \pm 0.001$ & $1.28 \pm 0.09$ \\
\hline OVERALL AVERAGE & & $0.018 \pm 0.004$ & $1.51 \pm 0.04$ \\
\hline
\end{tabular}




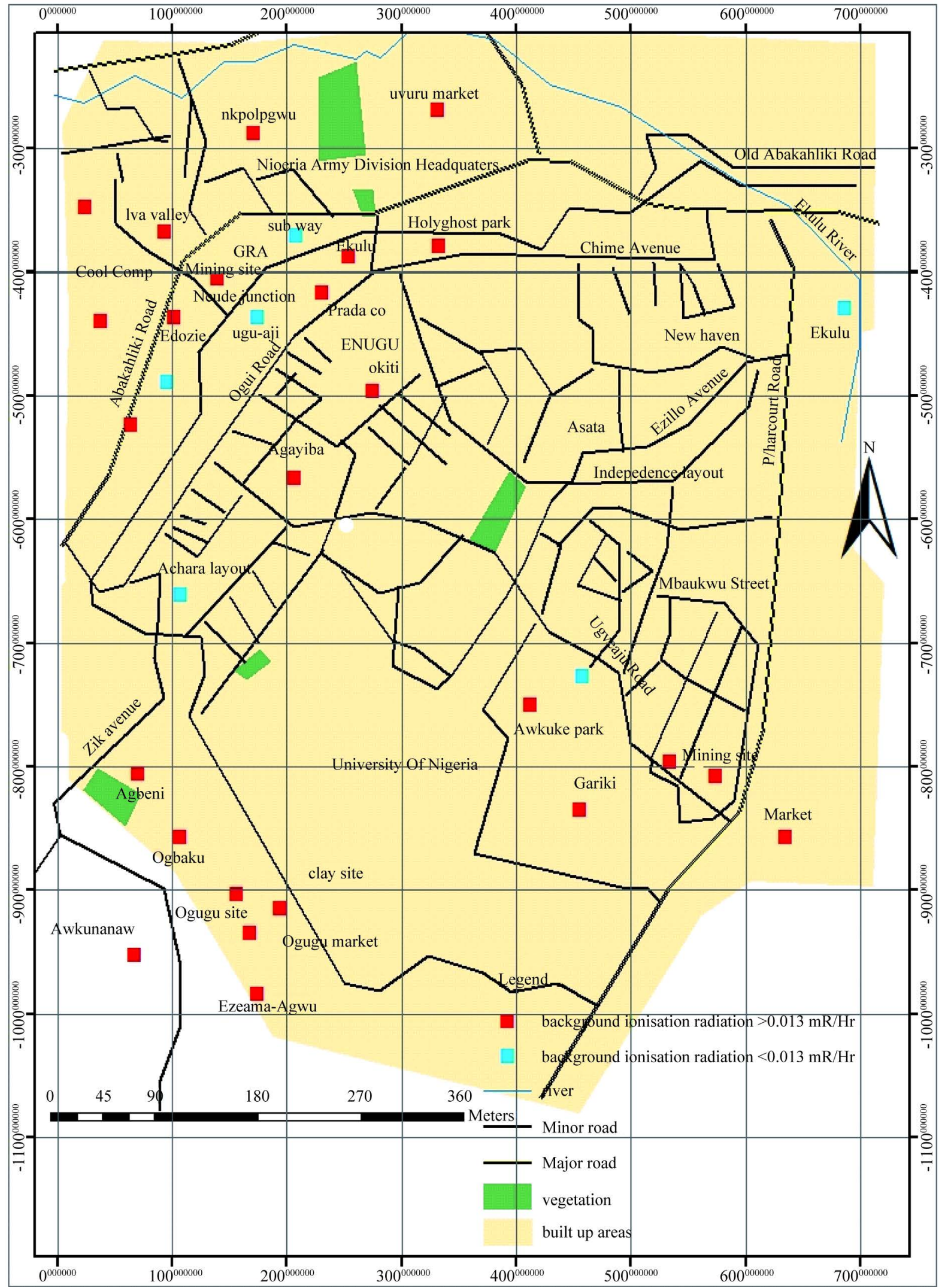

Figure 2. GIS mapping of BIR levels in some solid mineral producing areas of Enugu state, Nigeria. 
Table 2. Summary of the measured BIR from various mineral sites.

\begin{tabular}{cccc}
\hline Communities & Solid Minerals & Mean BIR Levels $(\mathbf{m R} / \mathbf{h r})$ & Equivalent Dose Rate $(\mathbf{m S v} / \mathbf{y r})$ \\
\hline Ogugu & Limestone & $0.016 \pm 0.005$ & $1.37 \pm 0.04$ \\
Enugu-Ekulu & Clay & $0.020 \pm 0.003$ & $1.64 \pm 0.24$ \\
Awgu & Bitumen & $0.019 \pm 0.007$ & $1.56 \pm 0.05$ \\
Awkuke & Ironstone & $0.020 \pm 0.00$ & $1.64 \pm 0.09$ \\
Ama-echi & Silica & $0.019 \pm 0.002$ & $1.58 \pm 0.19$ \\
Uzo-uwani & Kaolin & $0.014 \pm 0.008$ & $1.16 \pm 0.05$ \\
Enugu North & Gypsum & $0.017 \pm 0.002$ & $1.37 \pm 0.17$ \\
Nsude & Glass-sand & $0.015 \pm 0.001$ & $1.28 \pm 0.09$ \\
& & $\mathbf{0 . 0 1 8} \pm \mathbf{0 . 0 0 4}$ & $\mathbf{1 . 5 1} \pm \mathbf{0 . 0 4}$ \\
\hline
\end{tabular}

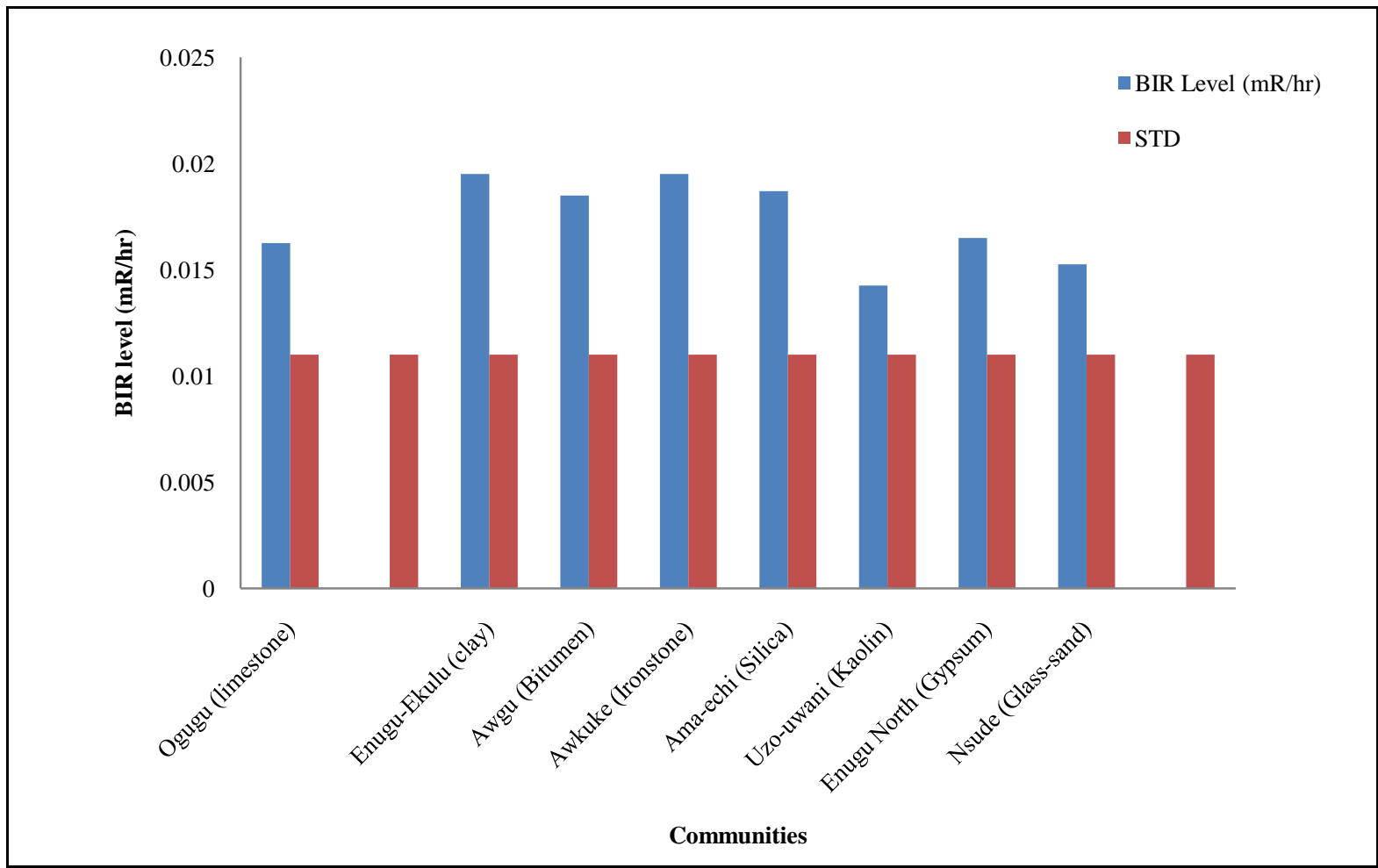

Figure 3. Showing comparison of the measured BIR with the international standard of $0.013 \mathrm{mR} / \mathrm{hr}$.

Figure 5. The result indicates that silica, ironstone and clay minerals each contributes about (14\%) to the Enugu environment BIR, with kaolin being the least contributor (10\%). As could be seen from the figure above, the background ionizing radiation measured from the study area is higher that the permissible values. Though the values obtained may not alarming for occupational miners who spend between 5 - 8 hours in these site but the value may be detrimental to those residing in these environment and those carrying out commercial activities in these environment that are face with constant exposure, there is therefore the need to check the exposure of life to prevent any possible hazards.

\section{Conclusion}

This study has revealed that the background ionizing radiation of the solid mineral producing areas of Enugu 


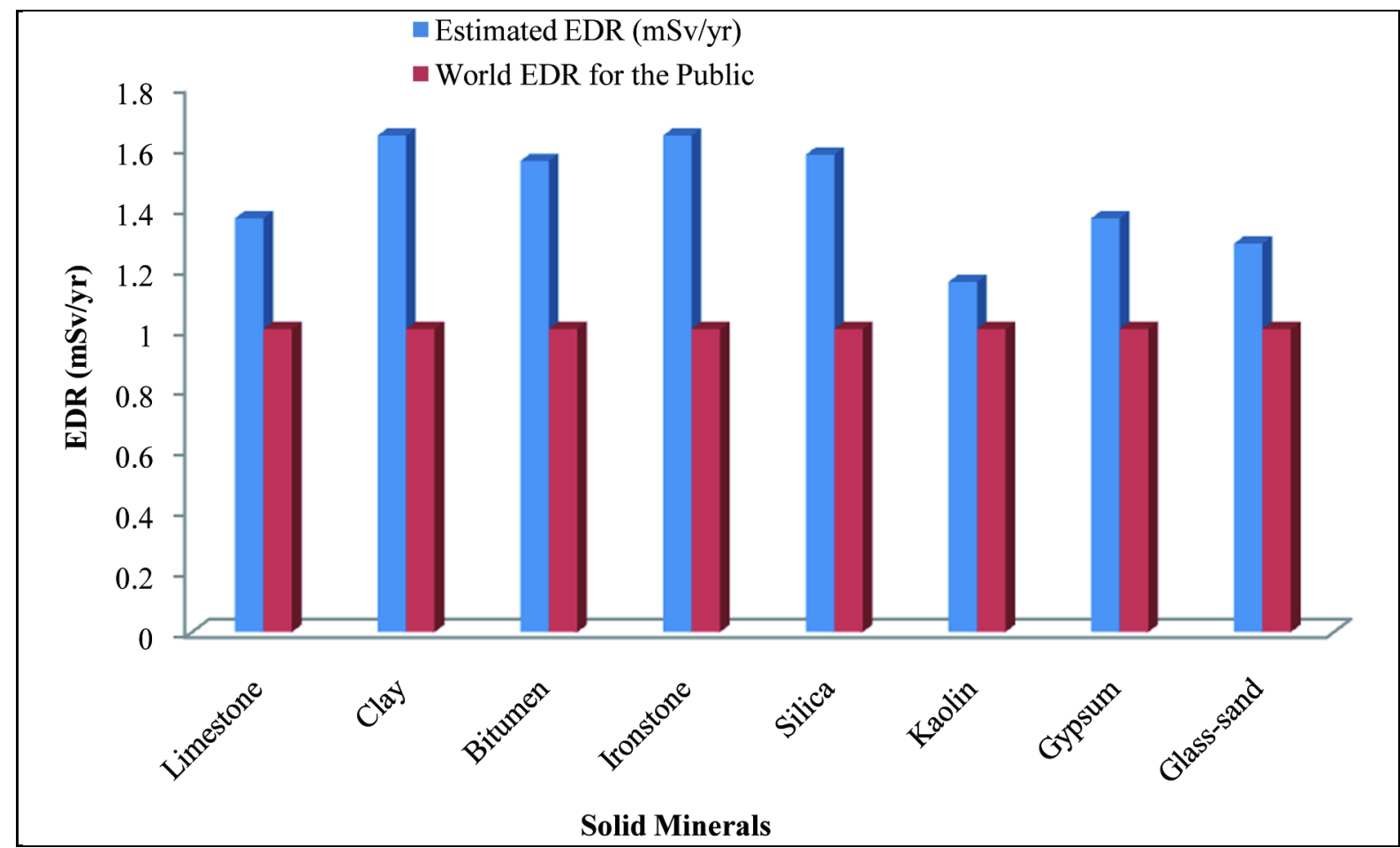

Figure 4. Comparison of the estimated EDR with the international standard of $1.0 \mathrm{mSv} / \mathrm{yr}$ for the public.

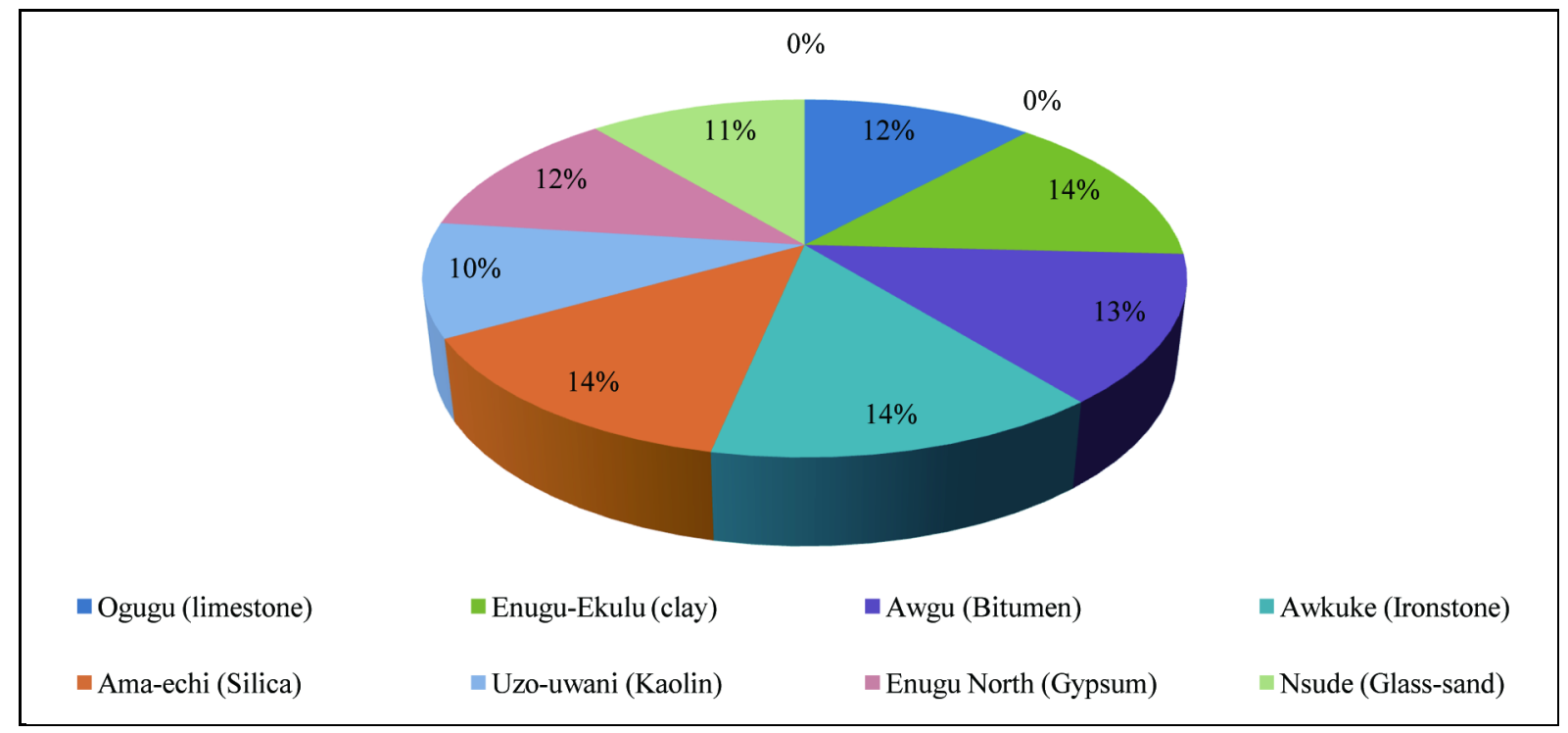

Figure 5. Percentage contributions of the various solid mineral to the total background ionizing radiation.

state has been found to be above international standard limit, and hence has been contaminated radiologically. The average BIR level in the mining sites in Enugu is $0.018 \pm 0.004 \mathrm{mR} / \mathrm{hr}$, indicating on the average $38.5 \%$ higher than the standard. From the ongoing, it is recommended that control mechanism should be adopted for the members of the public that approach the area as well as to protect the environment. Continuous or 24 hours commercial activities in the area and residing within three kilometre radius of these mining sites should be prohibited to avoid long-term accumulative health side-effect, while miners should be provided with Dosimetry to detect areas or spot with BIR level and to ascertain the dose levels accumulated within a given period for expert advice. 


\section{Acknowledgements}

The authors wish to appreciate the management of the Enugu State ministry of Environment for given all the needed support to this research work.

\section{References}

[1] Jibiri, N.N., Farai, I.P. and Ogunlana, A.M. (1999) Radioactivity Level of Some Nigerian Rock Samples. Nigeria Journal of Physics, 11, 220.

[2] Ballinger, P.W. (1991) National Radiation, Radiographic Position and Procedures. Mosby Year Book, 1, 21-32.

[3] Ramli, T.A., Aliyu, A.S., Agba, E.H. and Saleh, M.A. (2014) Effective Dose from Natural Background Radiation in Keffi and Akwanga Towns, Central Nigeria. International Journal of Radiation Research, 12, 47-52.

[4] Farai, I.P. and Vincent, U.E. (2006) Outdoor Radiation Level Measurement in Abeakuta Nigeria, by Thermoluminescent Dosimetry. Nigerian Journal of Physics, 18, 121-123.

[5] Adams, L. and Andrew, H. (1993) Hand Book of Radiation Effects. Oxford University Press, London, 2-41.

[6] Avwiri, G.O., Agbalagba, E.O. and Enyinna, P.I. (2010) Occupational Radiation Levels in Solid Mineral Producing Areas of Abia State. Scientia Africana, 9, 93-97.

[7] Dexter, P. (2002) Mineralogy. Pearson Education Inc., New York.

[8] Sadiq, A.A. and Agba, E.H. (2011) Background Radiation in Akwanga, Nigeria. Facta Universitatis; Series: Working and Living Environmental Protection, 8, 7-11.

[9] United Nations Scientific Committee on the Effects of Atomic Radiation (UNSCEAR) (2000) Sources and Effects of Ionizing Radiation (Report to the General Assembly). United Nation, New York.

[10] Enugu State Ministry of Environment and Mineral Development (2010) Enugu State Investment Potentials in Solid Minerals. Government Bulletin, 23.

[11] Ajayi, N.O. and Laogun, A.A. (2006) Variation of Environmental Gamma Radiation in Benin with Vertical Height. Nigerian Journal of Space Research, 2, 47-54.

[12] Avwiri, G.O., Egieya, J.M. and Ononugbo, C.P. (2013) Radiometric Survey of Aluu Landfill in Rivers State, Nigeria. Advances in Physics Theories and Applications, 22, 24-30.

[13] National Council on Radiation Protection and Measurements (NCRP) (1993) Limitation of Exposure to Ionizing Radiation: NCRP Report No. 116, March, National Council on Radiation Protection and Measurements, Bethesda, Maryland.

[14] Nwankwo, L.I. and Akoshile, C.O. (2005) Background Radiation Study of Offa Industrial Area of Kwara State, Nigeria. Journal of Applied Sciences and Environmental Management, 9, 95-98.

[15] Avwiri, G.O., Agbalagba, E.O. and Enyinna, P.I. (2007) Terrestrial Radiation around Oil and Gas Facilities in Ughelli Nigeria. Asian Network for Science Information. Journal of Applied Sciences, 7, 1543-1546. http://dx.doi.org/10.3923/jas.2007.1543.1546

[16] Agbalagba, E.O. and Meindinyo, R.K. (2010) Radiological Impact of Oil Spilled Environment: A Case Study of the Eriemu Well 13 and 19 Oil Spillage in Ughelli Region of Delta State, Nigeria. Indian Journal of Science and Technology, 2, 1001-1005. 